\title{
Expression of Glutamate Receptor Genes in White Matter: Developing and Adult Rat Optic Nerve
}

\author{
Abbie M. Jensen ${ }^{1, a}$ and S. Y. Chiu' ${ }^{2}$ \\ 'Neuroscience Training Program and 'Department of Neurophysiology, University of Wisconsin, Madison, Wisconsin 53706
}

\begin{abstract}
We have identified the glutamate receptor genes expressed by developing and adult rat optic nerve. Results from PCR suggested that of the ionotropic glutamate receptor (GluR) gene family, only GluR1 and GluR3 subunits are expressed by optic nerve. However, Northern blot analysis demonstrated that only the GluR1 subtype is expressed at appreciable levels. In situ hybridization histochemistry of GluR1 was performed and a diffuse pattern of expression was observed in both postnatal day 15 and adult optic nerve. Restriction mapping of the GluR1 PCR product indicated the expression of the flip alternative splice version in optic nerve. The detected GluR1 message was not due to axons because no loss of expression was observed after the degeneration of axons. PCR analysis also revealed the presence of a metabotropic glutamate receptor in optic nerve.

IKey words: ionotropic glutamate receptors, metabotropic glutamate receptors, glia, $0-2 \mathrm{~A}$ progenitor cells, optic nerve, white matterl
\end{abstract}

It is now cstablished that glial cells in the CNS express glutamate receptors (for reviews, see Pearce and Murphy, 1988; Barres, 1991) and thus may have an active role in brain signaling. Glial cells are heterogeneous with respect to brain regions (Wilkin et al., 1990), and may be functionally specialized according to their relations with different parts of a neuron. Broadly speaking, glial cells fall into two categories depending on their association with neuronal elements. In the gray matter, glial cells lie close to neuronal cell bodies, and send processes to encapsulate the synapse. Some suggested neuron-glial interactions in gray matter include glia as substrate for neuron migration (Rakic and Sidman, 1971), and neuron-to-glial signaling via glutamate released at the synapse (Dani et al., 1992). The second category of glia, white matter glia, are distributed along axon fibers rather than being in close proximity to neuronal cell bodies and synapses and are likely to be functionally specialized to interact with axons. White matter glia may influence the development

\footnotetext{
Received Aug. 3, 1992; revised Oct. 12, 1992; accepted Oct. 22, 1992.

We thank Carol Dizack and Terry Stewart for help in illustration and photog raphy, and Mary Bessey for technical assistance. We also thank Dr. D. O. Smith for providing us with the glutamate receptor primcrs, Dr. S. Hcinemann for the glutamate receptor cDNA clones, and Dr. Jim Boulter for his generous advice This work was supported in part by Grant NS-23375 from the U.S. Public Health Service, Grant RG-1839 from the U.S. National Multiple Sclerosis Society, and a Pew Scholar in the Biomedical Sciences award to S.Y.C., and an NIH Neuroscience training grant to A.M.J.

Correspondence should be addressed to Shing Yan Chiu, University of Wisconsin, Department of Neurophysiology, 283 Medical Sciences Building, 1300 University Avenue, Madison, WI 53706.

a Present address: University College London, Department of Biology, Gower Street, London WC1E 6BT, UK.

Copyright (C) 1993 Society for Neuroscience $0270-6474 / 93 / 131664-12 \$ 05.00 / 0$
}

of the node of Ranvier (for review, see Black and Waxman, 1988), participate in myelination, and support saltatory conduction.

Given these vastly divergent roles for white and gray matter glia, an issue of considerable interest is whether receptor properties are different or perhaps functionally specialized for the two glial categories. Although glutamate receptors in both white and gray matter glial have been extensively characterized at the cellular level using biochemistry (Pearce et al., 1986), electrophysiology (Sontheimer et al., 1988; Usowicz et al., 1989; Barres et al., 1990a,b; Wyllie et al., 1991; Berger et al., 1992), and calcium imaging (Enkvist et al., 1989; Cornell-Bell et al., 1990; Glaum et al., 1990; Jensen and Chiu, 1990, 1991a), it is only recently that studies have begun to identify the glutamate receptor genes expressed by glia. To date, the most comprehensive studies on the molecular identity of glutamate receptor genes have focused on gray matter glia (Keinanen et al., 1990; Pellegrini-Giampietro et al., 1991; Gallo et al., 1992). Here we first identify the glutamate receptor genes expressed by mammalian white matter that predominantly consists of glial and axonal elements but is completely devoid of neuronal cell bodies and synapses.

\section{Materials and Methods}

Polymerase chain reaction. The Fast Track (Invitrogen) mRNA isolation kit was used to isolate mRNA from postnatal day 2 (P2), P15, and adult optic nerves, P2 liver, and adult cerebellum that was used for reverse transcription reactions prior to PCR. The whole-brain MRNA was isolated using the method of Chomczynski and Sacchi (1987) and by oligodT column purification. The primers used for PCR were designed to amplify sequences approximately 700 base pairs in length that contained the flip/flop exon in GluR1-GluR4, and in GluR5, GluR6, and NMDA receptor (NMDAR) the sequence was in an analogous position to GluR1GluR4. The sequences of the oligonucleotide primers used in PCR reactions are given in Table 1 .

Reverse transcription reactions and DNA amplification were performed using the Perkin Elmer Cetus DNA thermal cycler and Gene $A m p$ RNA PCR kit, and followed the given protocol of that kit (Perkin Elmer Cetus). First-strand cDNA was synthesized from the mRNA using random hexamer primers. PCR reactions contained $60 \mathrm{ng}$ each of upstream and downstream primers, and concentrations of $\mathrm{MgCl}_{2}$ used in PCR reactions were determined empirically using cloned GluR cDNA, or brain mRNA, and were as follows (in mM): GluR1, 4.0; GluR2, 3.5; GluR3, 2.5; GluR4, 4.0; GluR5, 2.5; GluR6, 2.5; NMDAR1, 2.5; metabotropic GluR (mGluR), 2.5. PCR reactions $(100 \mu$ l) were 35 cycles in length $\left(95^{\circ} \mathrm{C}, 1 \mathrm{~min} ; 56^{\circ} \mathrm{C}, 1 \mathrm{~min} ; 72^{\circ} \mathrm{C}, 1 \mathrm{~min}\right.$; the third segment was automatically extended 5 sec each cycle; the final cycle was followed by $7 \mathrm{~min}$ at $72^{\circ} \mathrm{C}$ ). The mGluR PCR reactions used in restriction digestion experiments went through 40 cycles of amplification. All PCR reactions were repeated several times and gave similar results.

A volume (amount given in figure captions) from each of the PCR reactions was run on $1.8 \%$ agarose gels in $1 \times$ Tris-acetate EDTA running buffer; a DNA ladder [GIBCO/Bethesda Research Labs (BRL)] was used as a size standard. PCR products used in enzyme digestion reactions 
Table 1. Sequences of oligonucleotide primers used in PCR reactions

\begin{tabular}{lll} 
Gene & $\begin{array}{l}\text { Upstream primer }\left(5^{\prime} \rightarrow 3^{\prime}\right) \\
(\text { common upstream primer for }\end{array}$ & Downstream primer $\left(5^{\prime} \rightarrow 3^{\prime}\right)$ \\
\hline GluR1 & TGGTGGTTCTTCACCCTGATCAT & TATGGCTTCATTGATGGATTGC \\
GluR2 & TGGTGGTTCTTCACCCTGATCAT & TGCAAAATCTGGGAATCTGC \\
GluR3 & TGGTGGTTCTTCACCCTGATCAT & AATTCTGAGTGTTGGTGGCAGG \\
GluR4 & TGGTGGTTCTTCACCCTGATCAT & ACTCCCAGTGATGGATAACCTG \\
GluR5 & TGGTGGTTCTTCACCCTGATCAT & CACTGCTCAACGTCATTGTTCT \\
GluR6 & GGAGCCCAGGATGATGTGAAC & GTATACGAAGAAATGATGAT \\
NMDAR & CTGTGGTTGCTAGTAGGACTGT & GCATTCCTGATACCGAACCCA \\
mGluR & TGTGAGCCCATTCCTGTCCGTT & CGGTTGAAGTTACTCCGATTTA \\
\hline
\end{tabular}

were initially purified using PCR Magic columns (Promega); digested reactions were also run on $1.8 \%$ agarose gels; DNA was visualized by ethidium bromide staining of the gels.

Northern blot analysis. Total RNA from P15 (40 animals) and adult (30 animals) rat optic nerve (anterior to the optic chiasm), and rat cortex was isolated according to the method of Chomczynski and Sacchi (1987). Approximately $25 \mu \mathrm{g}$ total RNA/lane from PI5 and adult optic nerve and cortex was separated on a $1 \%$ formaldehyde-agarose gel and transferred to Durlon membrane (Stratagene). The RNA molecular weight ladder from GIBCO/BRL was used to standardize the target mRNA sizes. Partial-length probes of GluR1 [1.6 kilobase (kb) EcoRI-BamHI fragment], GluR2 (1.4 kb SmaI-Ra/l fragment), and GluR3 (1.3 kb SacI fragment) were labeled with ${ }^{35} \mathrm{~S}$ (Amersham) by the random prime method (Random Primed DNA Labeling Kit, Boehringer Mannheim). All of these fragments are at the $5^{\prime}$ end of the cloned sequences and do not contain the flip/flop alternate splice exons. Unincorporated nucleotides were removed by spin columns (Boehringer Mannheim). Also, the percentage of radionucleotide incorporalion was tested by trichloroacetic acid precipitation. Following $2 \mathrm{hr}$ of prehybridization at $42^{\circ} \mathrm{C}$, the membrane was incubated overnight at $42^{\circ} \mathrm{C}$ with $1-2 \times 10^{6} \mathrm{cpm} / \mathrm{ml}$ hybridization solution. The membrane was washed in $2 \times$ saline-sodium citrate (SSC), $0.2 \%$ SDS for $10 \mathrm{~min}$ at $42^{\circ} \mathrm{C}, 2 \times \mathrm{SSC}, 0.2 \% \mathrm{SDS}$ for 30 $\mathrm{min}$ at $65^{\circ} \mathrm{C}$, and $0.1 \times \mathrm{SSC}, 0.1 \% \mathrm{SDS}$ for $10 \mathrm{~min}$ at room temperature. The membrane was exposed to $\mathrm{x}$-ray film for the indicated times with intensifying screens at $-70^{\circ} \mathrm{C}$. Between the sequential hybridizations, the probe was removed hy washing the membrane in $6 \times$ SSC, $50 \%$ formamide at $65^{\circ} \mathrm{C}$ for $40 \mathrm{~min}$, was reexposed to $\mathrm{x}$-ray film for 1 week (no remaining signal was detected), and subsequently was not rehybridized until months later.

In situ hybridization histochemistry. Optic nerves (anterior to the optic chiasm) and brains were isolated, fixed overnight in $4 \%$ paraformaldehyde at $4^{\circ} \mathrm{C}$, dehydrated, embedded in paraffin, sectioned at a thickness of $8 \mu \mathrm{m}$, and mounted on slides coated with gelatin and poly-Llysine. Paraffin was removed with two xylene treatments ( 10 min each), and the samples were rehydrated through an ethanol series. Tissues were incubated in $0.1 \mathrm{M}$ triethanolamine $(\mathrm{pH} 8.0)$ plus $0.25 \%(\mathrm{v} / \mathrm{v})$ acetic anhydride, briefly washed in $2 \times$ SSC, and dehydrated through a series of ethanol concentrations. Full-length antisense and sense RNA probes were prepared by in vitro transcription (Stratagene) with T7 (antisense) or T3 (sense) polymerase using linearized, subcloned GluR 1 cDNA in pBluescript SK $(-)$ vector. Unincorporated nucleotides were removed by both running the transcription reaction through a push column (Stratagene) and then by ethanol precipitation. Probes were denatured at $80^{\circ} \mathrm{C}$ for $5 \mathrm{~min}$, mixed with hybridization solution $(50 \%$ formamide, $4 \times$ SSC, $1 \times$ Denhardt's solution, $0.5 \mathrm{mg} / \mathrm{ml}$ herring sperm DNA, 0.25 $\mathrm{mg} / \mathrm{ml}$ yeast (RNA, $5 \%$ dextran sulfate) to give a probe concentration of $4 \times 10^{6} \mathrm{cpm} / \mathrm{ml}$ hybridization solution. Tissues were then incubated in $60 \mu \mathrm{l}$ of hybridization solution beneath a coverslip $(22 \times 50 \mathrm{~mm})$ that was sealed with DPX mountant (Fluka). Hybridization was for at least $18 \mathrm{hr}$ at $60^{\circ} \mathrm{C}$. Tissues were washed twice in $4 \times \mathrm{SSC}, 10 \mathrm{~mm}$ dithiothreitol (DTT) at room temperature for 15-20 min, and once in $4 \times$ SSC, $50 \%$ formamide, $10 \mathrm{~mm}$ DTT at $55^{\circ} \mathrm{C}$ for $30 \mathrm{~min}$. Tissues

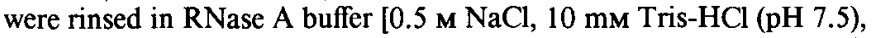
$1 \mathrm{~mm}$ EDTA] and then incubated in RNase A $(20 \mu \mathrm{g} / \mathrm{ml})$ in RNase $A$ buffer at $37^{\circ} \mathrm{C}$ for $30 \mathrm{~min}$. Tissues then were washed at room temperature in $2 \times$ SSC + $10 \mathrm{~mm} \mathrm{DTT,} 1 \times \mathrm{SSC}+10 \mathrm{~mm} \mathrm{DTT}$, and $0.5 \times \mathrm{SSC}+$
mM DTT, each for $15 \mathrm{~min}$. Finally, tissues were washed in $0.1 \times \mathrm{SSC}$ at $55^{\circ} \mathrm{C}$ for $30 \mathrm{~min}$, and then rinsed briefly in $0.1 \times \mathrm{SSC}$ at room temperature and dehydrated through an ethanol series.

To determine whether the hybridization signal was RNA specific control sections were subjected to RNase treatment prior to the hybridization step. Following the acetic anhydride treatment and brief rinse in $2 \times \mathrm{SSC}$, the sections were rinsed in RNase A buffer [0.5 $\mathrm{M}$ $\mathrm{NaCl}, 10 \mathrm{~mm}$ Tris- $\mathrm{HCl}$ (pH 7.5), 1 mM EDTA], and then transferred to prewarmed RNase A buffer containing $30 \mu \mathrm{g} / \mathrm{ml}$ RNase A (Boehringer Mannheim) and incubated for $30 \mathrm{~min}$ at $37^{\circ} \mathrm{C}$. Another $15 \mu \mathrm{g} / \mathrm{ml}$ of RNase A was added to the buffer and the incubation continued for another $30 \mathrm{~min}$. Sections were then rinsed in $2 \times$ SSC, and the hybridization with labeled $\mathrm{CRNA}$ probes and posthybridization washes were performed as described above.

Slides were dipped in NTB-2 nuclear emulsion (Kodak) diluted 1:1 with $600 \mathrm{~mm}$ ammonium acetate and exposed for the indicated times at $4^{\circ} \mathrm{C}$. Slides were developed for $3 \mathrm{~min}$ in D19 (Kodak) and fixed for $2 \mathrm{~min}$. Tissues were then counterstained with cresyl violet (2-3 $\mathrm{min}$ ), dehydrated, passed through three changes of xylene, and mounted beneath a coverslip with DPX mountant (Fluka).

Silver grain density was assessed by taking both dark-field and brightfield photograghs of optic nerve sections (magnification, 550x) exposed for $13 \mathrm{~d}$ (counting silver grains was difficult at longer exposure times) and counting the number of silver grains (dark field) and the number of cresyl violet-stained nuclei (bright field) in the same field. The number of silver grains was divided by the number of nuclei to give the average number of grains per nuclei.

Treatment of optic nerve sections with RNase A prior to hybridization with GluR 1 antisense probe significantly reduced the number of silver grains ( $t$ test; $p<0.0001, \mathrm{P} 15$ optic nerve; $p<0.0003$, adult optic nerve).

Optic nerve dissection for PCR analysis. Optic nerves were dissected from Sprague-Dawley rats, ages P2, P15, P21, and adult. Following decapitation, ocular muscles were cut, nerves were cut anterior to the optic chiasm, the eyeball along with the nerve was retracted, and the eye was then cut from the nerve. Optic nerves were frozen in liquid nitrogen and used immediately for $\mathrm{mRNA}$ isolation or frozen at $-70^{\circ} \mathrm{C}$ until further use.

Optic nerve transection. Seven adult and 12 P15 rats were anesthetized, adults by intramuscular injection of ketamine $(80 \mathrm{mg} / \mathrm{kg})$ and xylazine $(10 \mathrm{mg} / \mathrm{kg})$ and $P 15$ rats by inhalation of methoxyflurane. The left optic nerve was transected behind the eye. The right optic nerve remained intact to serve as control. The eyelids of adult rats were suturcd together. The animals were killed 5-6 d following surgery; transected and intact optic nerves were dissected as described above.

\section{Results}

The rat optic nerve was chosen for this study for several reasons. First, this white matter is completely devoid of neuronal cell bodies, and can be easily obtained in sufficent quantities for analysis without contamination from gray matter tissues. Second, the developmental sequence of cell migration, proliferation, and differentiation of glial cells in the rat optic nerve has been extensively characterized (Raff, 1989). Finally, knowledge 

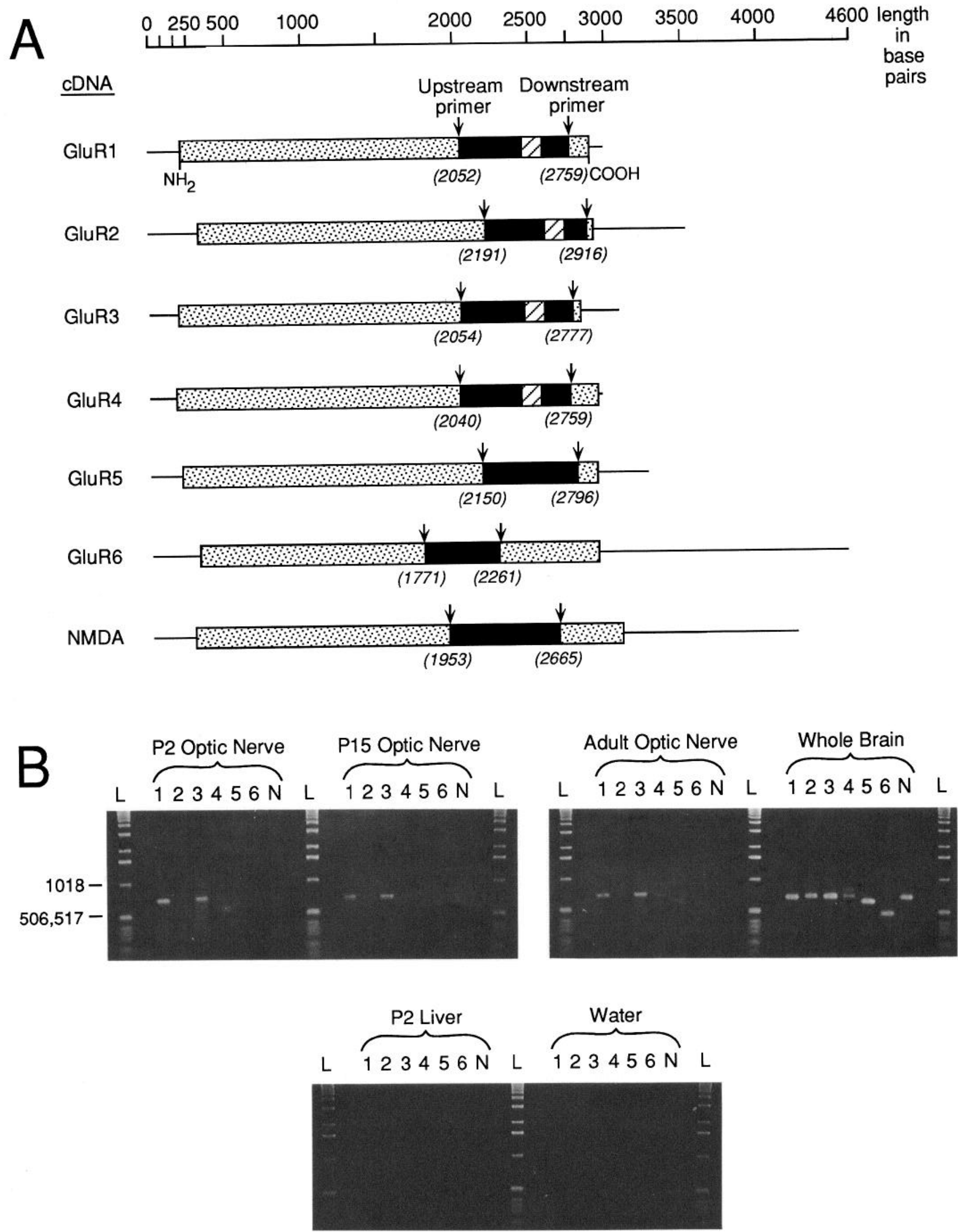


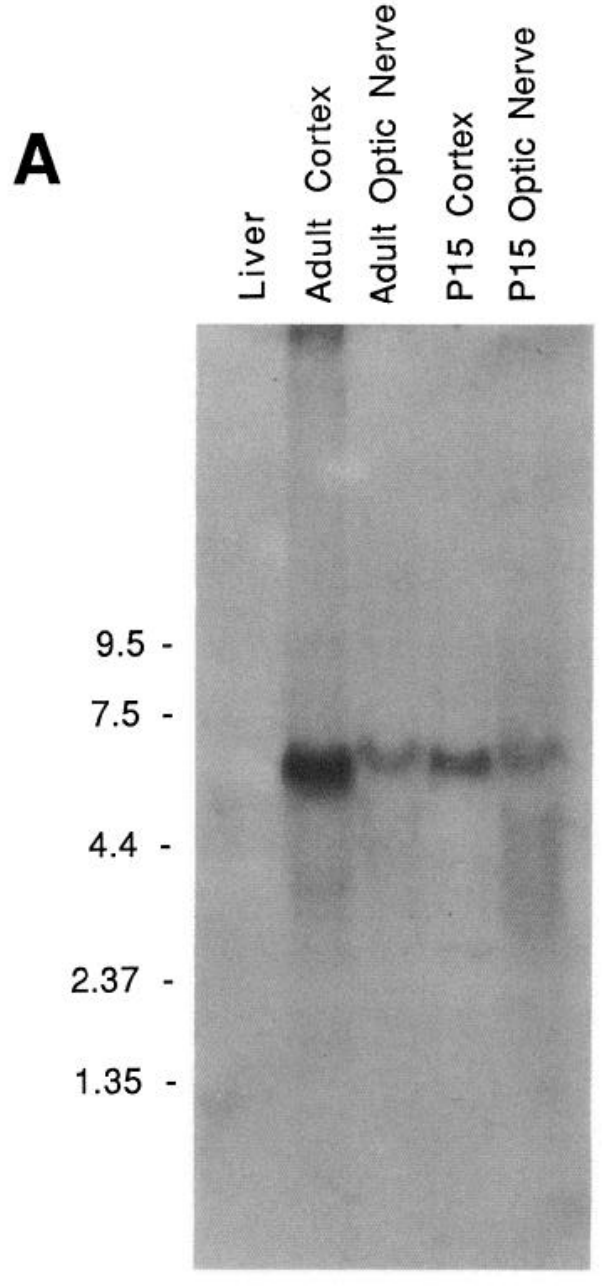

\section{GluR1}
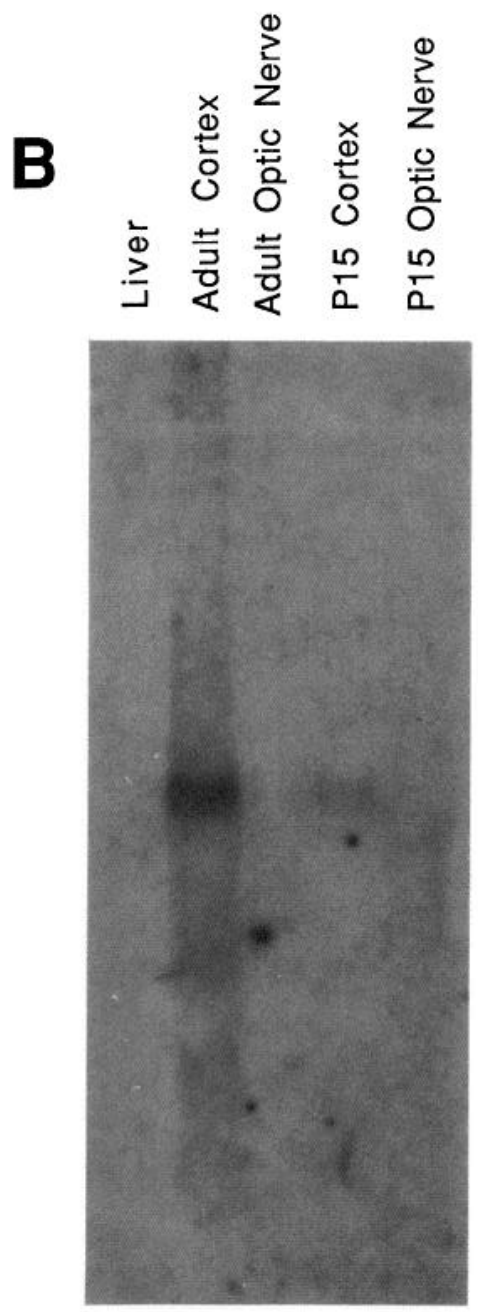

GluR3
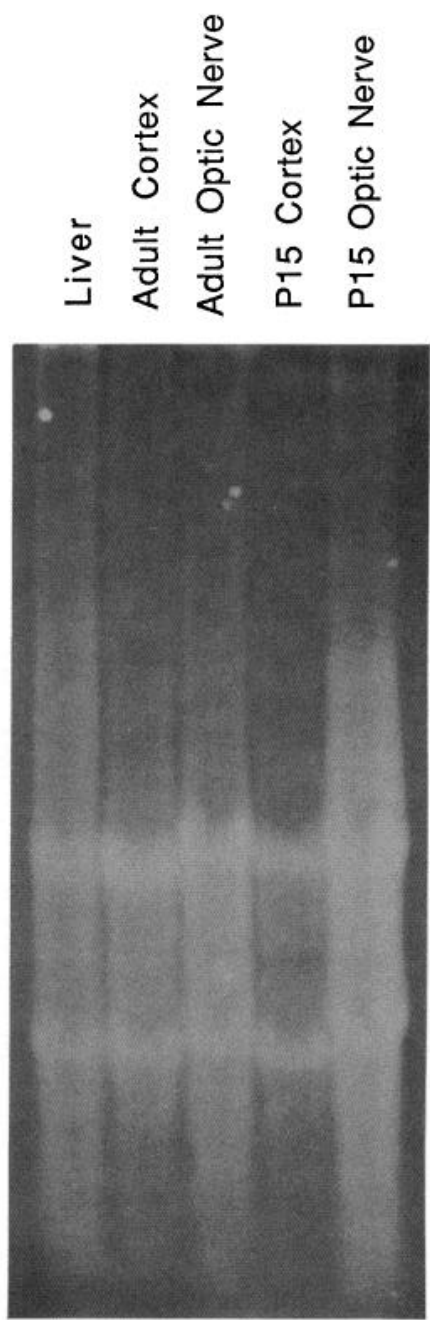

EthBr

Figure 2. Northern blot analysis of GluR1 and GluR3 genes in P15 and adult optic nerve. $A$, Total RNA ( $\sim 25 \mu \mathrm{g} /$ lane) isolated from P15 optic nerve, P15 cortex, adult optic nerve, adult cortex, and liver was hybridized with a GluR1 probe exposed to x-ray film for $3 \mathrm{~d}$. $B$, The same blot as $A$ rehybridized with a GluR3 probe (see Materials and Methods), exposed to x-ray film for $7 \mathrm{~d}$. $C$, An ethidium bromide (EthBr) stain of the gel prior to RNA transfer, showing the relative amount of RNA loaded in each lane. The molecular weight RNA standard (GIBCO/BRL) was used to size the hybridization signal.

of glutamate receptor expression in rat optic nerve may provide insight into the mechanisms of receptor-mediated signaling in nonsynaptic regions of the brain.

\section{PCR analysis of GluR genes in developing and adult optic nerve}

Because rat optic nerve tissue is small, especially in neonatals, PCR first was used to identify genes for the GluR subtypes that had the highest potential of being expressed at levels abundant enough for further analysis. Figure 1 shows the results of PCR using mRNA isolated from P2, P15, and adult optic nerve, adult whole brain (positive control), and P2 liver (negative control). Primers for PCR were designed according to published sequences of members of the GluR family: GluR1 (Hollmann et al., 1989; GluR-A, Keinanen et al., 1990), GluR2 (Boulter et al., 1990; GluR-B, Keinanen et al., 1990; GluR-K2, Nakanishi et al., 1990), GluR3 (Boulter et al., 1990; GluR-C, Keinanen et al., 1990; GluR-K3, Nakanishi et al., 1990), GluR4 (Bettler et al., 1990; GluR-D, Keinanen et al., 1990), GluR5 (Bettler et al., 1990), GluR6 (Egebjerg et al., 1991), and NMDAR (Moriyoshi et al., 1991; Kumar et al., 1991). Following reverse transcription of mRNA with random hexamer primers, oligomer primer pairs selective for each GluR subtype (see Materials and Methods)

Figure 1. PCR analysis of GluR genes in rat optic nerve. A, Schematic illustrations of GluR genes tested for in PCR; coding regions are indicated by stippled boxes, region targeted for PCR amplification by solid boxes, flip/flop alternately spliced exons by hatched boxes (GluR1, GluR2, GluR3, GluR4). The first base of the upstream primer site and the last base of the downstream primer site are indicated with arrows and the numbers given below each gene in parentheses. $B$, Visualization of PCR products by gel electrophoresis and ethidium bromide staining. A portion (10 $\mu$ l) of the PCR reaction was run on $1.8 \%$ agarose gels. The gene tested for is indicated above each lane ( 1 , GluR1; 2, GluR2, etc.; $N$, NMDAR). The same amount of mRNA was added to all reactions within each group (i.e., all P2 optic nerve reactions had same amount of mRNA) but the amount of mRNA between groups was not equalized (i.e., mRNA in P2 optic nerve reactions not necessarily equal to that in P15 optic nerve reactions). The sizes of the PCR products are standardized according to the size ladder (GIBCO/BRL) flanking each group of reactions as indicated by $L$. 


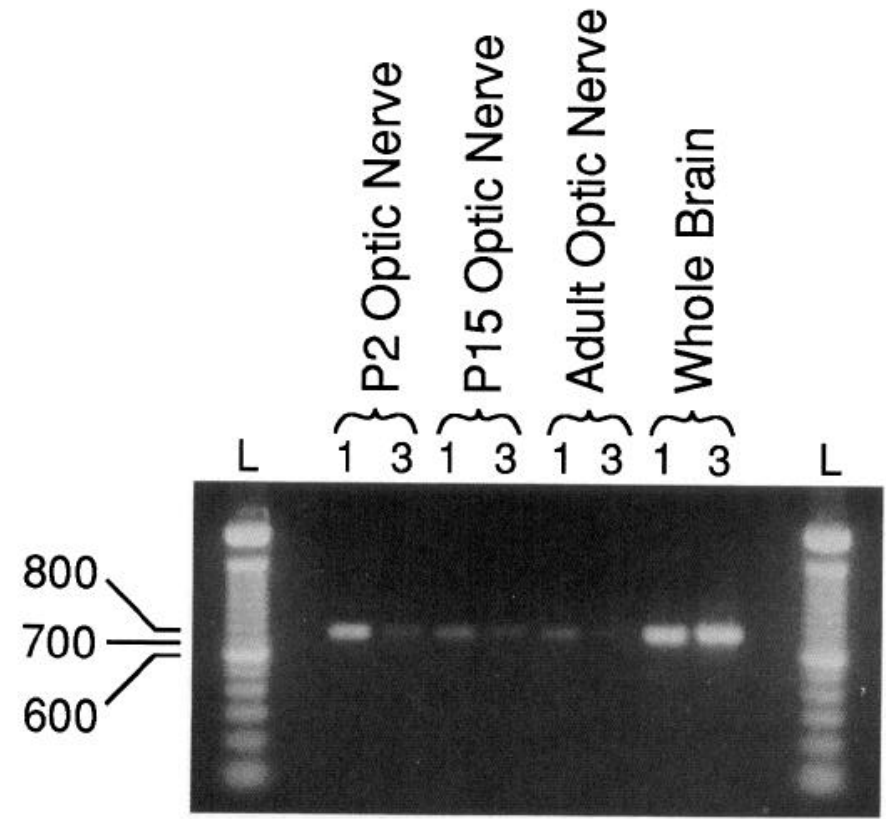

Figure 3. Comparison of GluR1 and GluR3 gene expression in rat optic nerves at 30 cycles of PCR. In PCR reactions (as in Fig. 1) that employed 35 cycles of amplifications, the amplified signals for GluR1 (I) and GluR3 (3) in rat optic nerves were similar in intensity. The data in this figure show that when the number of cycles was reduced to 30 , GluR 1 in optic nerves is amplified to a larger extent in comparison with GluR3. Experimental conditions in this figure were essentially the same as in Figure 1 except in the number of cycles used. The sizes of the PCR products are standardized according to the size ladder (GIBCO/ BRL) flanking the PCR reactions as indicated by $L$.

were used to amplify target DNA sequences with the following predicted molecular weights (in base pairs): GluR1, 707; GluR2, 726; GluR3, 724; GluR4, 720; GluR5, 647; GluR6, 492; NMDAR, 713 (Fig. 1A, solid boxes). The PCR target sequences of GluR1, GluR2, GluR3, and GluR4 contained the alternately spliced flip/flop exon (Fig. $1 A$, hatched boxes).

In optic nerve of all ages studied, target sequences of the predicted molecular weights for GluR1 and GluR3 are selectively amplified when compared to those of GluR2, GluR4, GluR5, GluR6, and NMDAR (Fig. 1B). The results shown in Figure 1 were consistantly reproducible (five experiments). In all PCR experiments, the same amount of starting mRNA was added to each reaction within each group (e.g., equal amounts of mRNA in each P2 optic nerve reaction) but not across groups (amount of mRNA in P2 reactions was not equal to that in P15 optic nerve reactions). Since the amount of mRNA isolated from optic nerve was small, no attempt was made to quantify the amount of mRNA added to the reactions. In contrast to optic nerve, all GluR subtypes were amplified, as expected, in wholebrain mRNA (Fig. 1B). As predicted, no GluR subtypes, as assessed by PCR, were present in mRNA isolated from P2 liver. It is unlikely that the GluR1 and GluR3 PCR products are results of amplification of contaminating genomic DNA. The closely related GluR2 gene (GluR-B, Sommer et al., 1990), like GluR1 and GluR3, has alternatively spliced flip and flop exons and intron DNA that lie within the primer sites. If a similar case applies for GluR1 and GluR3, then PCR product would be much larger than that observed if there was contamination by genomic DNA.
Northern blot analysis of GluR gene expression in developing and adult rat optic nerve

Northern blot analysis of P15 and adult optic nerve RNA was performed to confirm the PCR results and to give a more quantitative measure of the expression level. Figure $2 A$ shows Northern blot analysis of total RNA isolated from optic nerve and cortex of P15 and adult rats that was hybridized with a GluR1specific probe. The GluR 1 probe hybridized, at high stringency, to a $5.2 \mathrm{~kb}$ transcript that is present in cortex and optic nerve of both adult and P15 rats but is absent in RNA from liver.

Figure $2 B$ shows the same blot rehybridized with a GluR3specific probe after the GluR1 probe had been removed (see Materials and Methods). The GluR3 probe hybridized in cortex (adult and P15) but little or no signal is present in the optic nerve lanes. No obvious loss of RNA was observed following the removal of the GluR 1 probe as measured by methylene blue staining of the blot (not shown). The lack of expression as measured by Northern blot analysis was puzzling in light of the PCR results (Fig. $1 B$ ) where GluR3 seemed to be amplified as strongly as GluR1 in optic nerve. One explanation is that even though GluR3 is much lower than GluR1 in the starting mRNA sample, the PCR reactions had reached similar amplification plateaus for both genes by the 35 cycles used in most experiments. This possibility was tested by reducing the number of cycles to 30 , and indeed GluR 1 amplification was clearly greater than GluR3 (Fig. 3).

In addition to hybridization with GluR1 and GluR3, GluR2 was hybridized to the same blot and no signal was detected in the optic nerve lanes after 2 weeks of exposure (data not shown).

Due to the differences in the amount of RNA present in each lane as shown by ethidium bromide staining of the gel before transfer to the filter (Fig. $2 C$ ) and also by methylene blue staining of the filter after transfer (not shown), it is difficult to make quantitative measurements of changes in GluR 1 expression between the tissue types or developmental changes in expression levels. However, as the intensity of the hybridization signal was approximately equal in adult and P15 optic nerve lanes and yet more RNA was present in the P15 optic nerve lane than in the adult optic nerve lane, the Northern blot results suggest there is a higher level of expression in adult optic nerve. Although it is clear that overall expression of GluR1 is less in optic nerve than in cortex, Northern blot analysis does not exclude the possibility that a subset of optic nerve cells abundantly express GluR1.

\section{In situ hybridization histochemistry of GluR1 in} developing and adult rat optic nerve

Neither PCR analysis nor Northern blot analysis provides information about the distribution of GluR expression in optic nerve; for instance, it could be that a subset of glial cells express GluR 1 at high levels, or many glial cells express GluR 1 but at low levels, or expression lies somewhere between these two extremes. In order to determine if there was a pattern of GluR 1 expression in optic nerve, in situ hybridization histochemistry was performed. Longitudinal sections $(8 \mu \mathrm{m})$ of P15 and adult optic nerve were hybridized with a GluR1 antisense riboprobe (upper left panels of Fig. $4 A, B$ ). Also shown, for comparison, is the hybridization of GluR 1 sense riboprobe to P15 and adult optic nerve (upper right panels of Fig. $4 A, B$ ) illustrating the level of background signal. The position of cell nuclei within P15 and adult optic nerve is revealed by cresyl violet staining (corre- 


\section{A \\ P15 OPTIC NERVE}

\section{GluR1 Antisense}
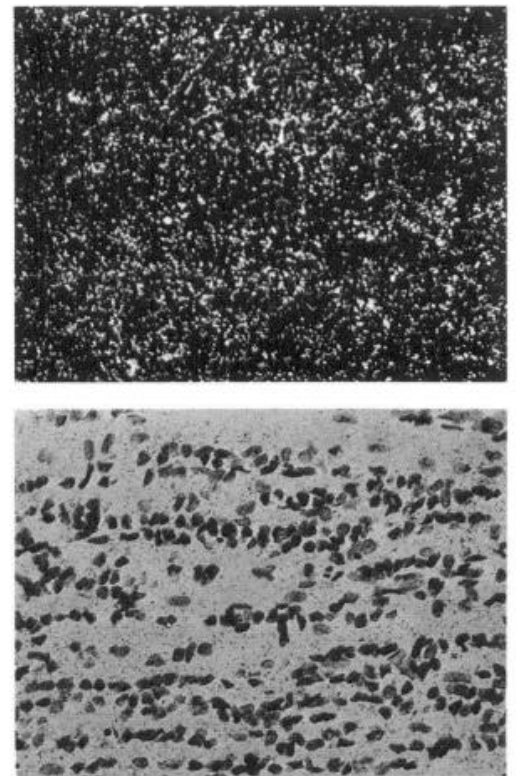

\section{GluR1 Sense}
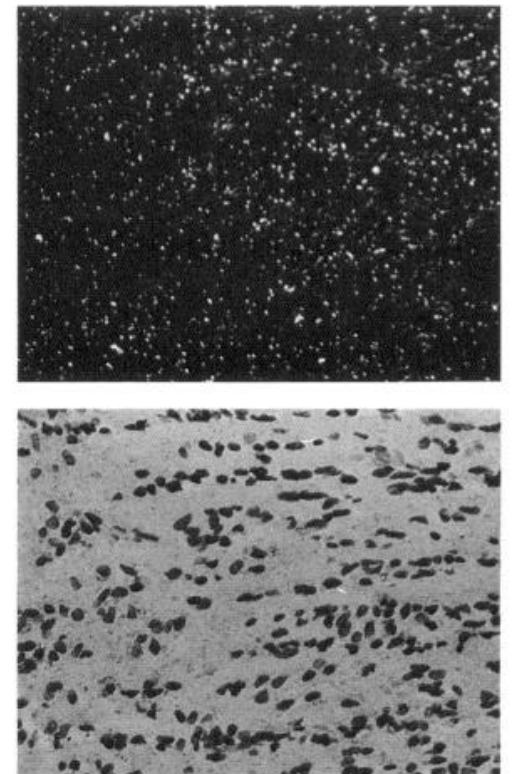

\section{B \\ ADULT OPTIC NERVE}

\section{GluR1 Antisense}
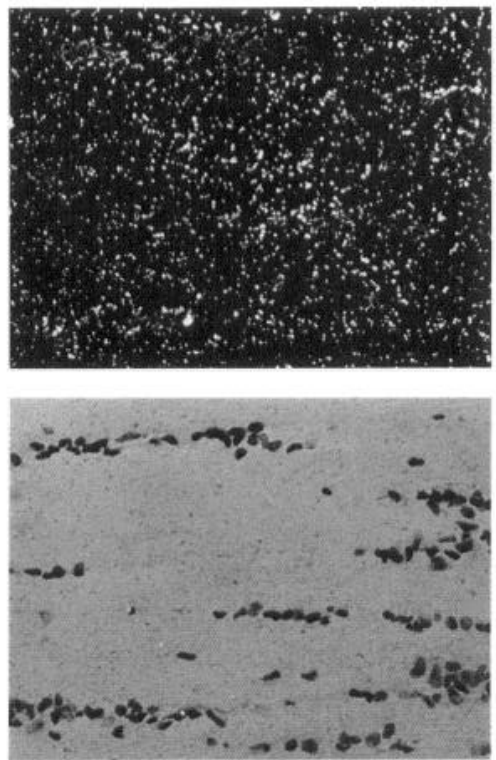

\section{GluR1 Sense}
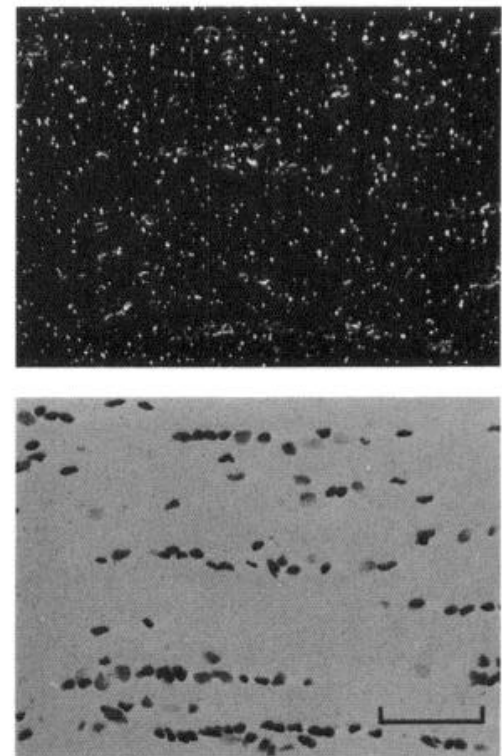

Figure 4. In situ hybridization histochemistry of the GluR 1 gene in P15 and adult optic nerve. Paraffin sections (8 $\mu \mathrm{m}$ ) of optic nerve (P15 and adult) were hybridized with a full-length GluR 1 riboprobe (see Materials and Methods). Sections were dipped in emulsion, exposed for 5 weeks, developed, and counterstained with cresyl violet. $A$ : Upper panels, Dark-field photos of silver grains showing the hybridization of GluR 1 antisense riboprobe (upper left) and GluR 1 sense riboprobe (upper right) to P15 optic nerves. Lower panels, Bright-field photos of the same field of view as corresponding upper panels showing nuclei stained with cresyl violet. B: Upper panels, Dark-field photos of silver grains showing the hybridization of GluR 1 antisense riboprobe ( $u p$ per left) and GluR1 sense riboprobe (upper right) to adult optic nerves. Lower panels, Bright-field photos of the same field of view as corresponding upper panels showing nuclei stained with cresyl violet. Scale bar, $50 \mu \mathrm{m}$. sponding lower panels of Fig. $4 A, B$ ). Sections of rat brain were hybridized in parallel (data not shown) with the optic nerve sections in order to judge the quality of the probe and hybridization conditions; the hybridization pattern was the same as those previously published (Boulter et al., 1990; Sommer et al., 1990).
A diffuse pattern of GluR 1 expression is seen in P15 and adult optic nerve (Fig. 4). The pattern of GluR1 expression in optic nerve does not appear to be due to axonal expression because if axons contained mRNA for GluR1, then silver grains would be more prominent over axon bundles, or those areas not occupied by glial cell bodies. In the optic nerve, glial cells tend to 


\section{A Map of restriction enzyme sites in GluR1 DNA amplified by PCR}
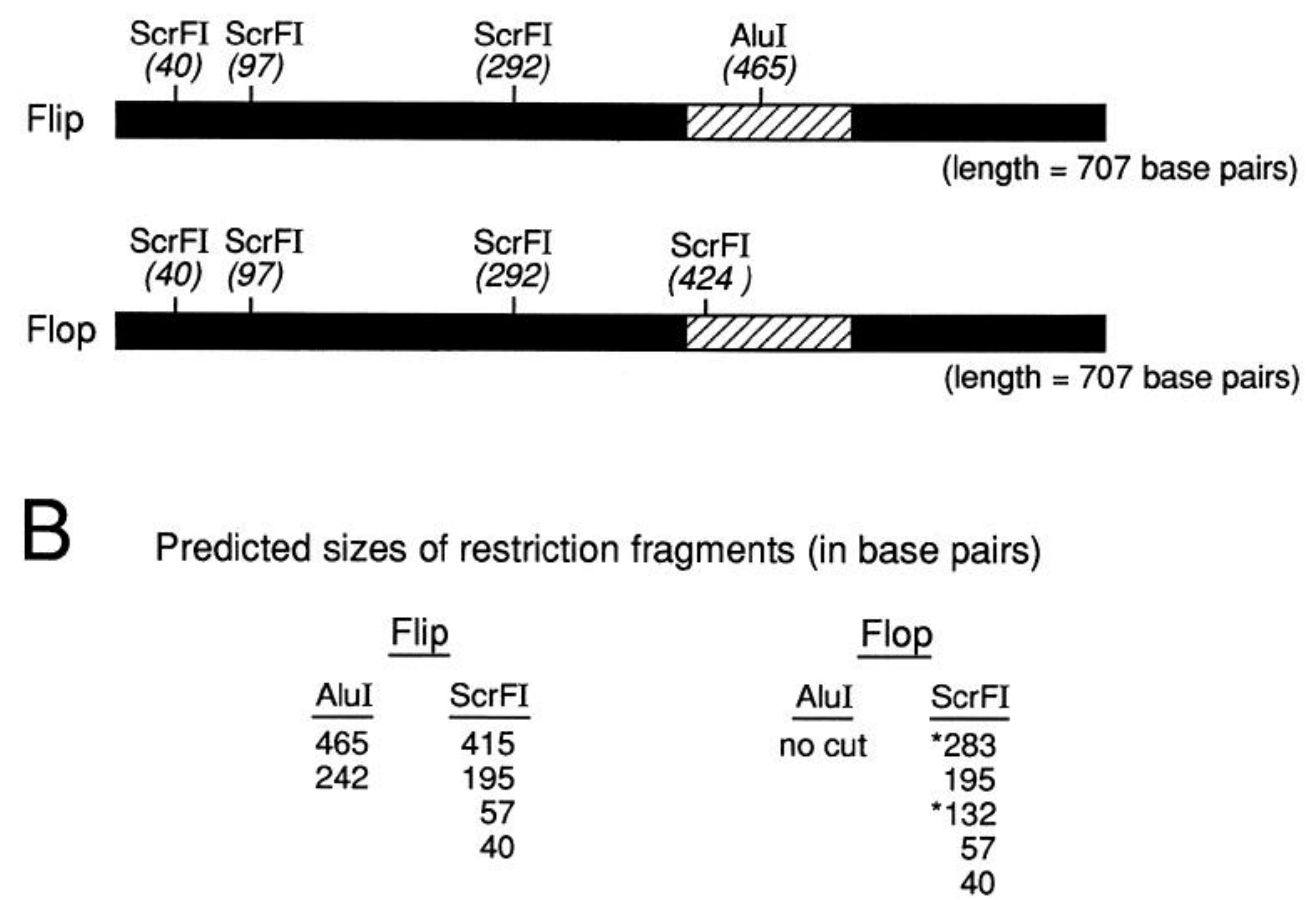

Figure 5. Restriction map of GluR1 PCR product. A, Map of AluI and ScrFI restriction sites in the region of the GluR 1 gene amplified by PCR. Both the flip and flop versions of the GluR 1 gene are illustrated. $B$, Predicted sizes of the fragments generated by enzymatic digestion with $A l u \mathrm{I}$ and $S c r F \mathrm{I}$ in the cases of flip or flop expression. *, fragments not present in the flip version. $C$, Uncut PCR product and AluI and $S c r F I$ enzymatic digestions and of P2, P15, adult optic nerve and wholebrain GluR1 PCR products were run on a $1.8 \%$ agarose gel and stained with ethidium bromide. Molecular weights are standardized with the DNA ladder $(L)$ from GIBCO/BRL.

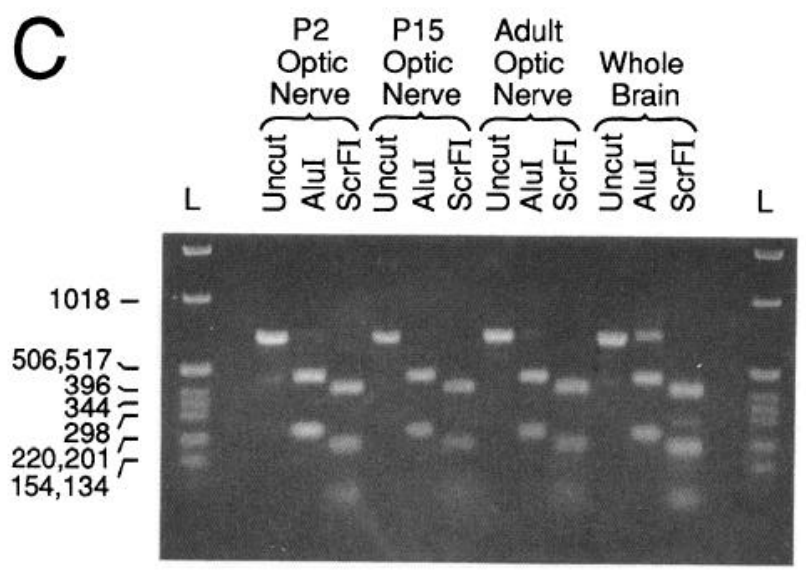

be positioned in rows with axon bundles lying between the glial rows; this is more pronounced in adult optic nerve (lower panels of Fig. $4 B$ ). There seems to be a slightly higher grain density near glial cells than within axon bundles (upper left panels of Fig. $4 A, B$ ). However, the unlikely possibility that axons contain some GluR1 transcripts cannot be discounted. Furthermore, GluR1 does not appear to be expressed by endothelial cells, as blood vessels were occasionally noticable within the optic nerve sections, and no increase in silver grain density above background was observed.

The overall density of silver grains is greater in P15 optic nerve than in adult optic nerve, but so is the density of nuclei (Fig. 4). When the number of grains is counted (13 d exposure; see Materials and Methods) and normalized to the number of nuclei, there is about a twofold increase in the average number of grains per nuclei in adult optic nerve ( 9.9 grains/nuclei) as compared to that in P15 optic nerve (3.9 grains/nuclei), which is statistically significant ( $t$ test, $p<0.0001)$. This increase is consistent with the Northern blot analysis of GluR1 in P15 and adult optic nerve.

In consideration of the results of GluR 1 in situ hybridization histochemistry that revealed a diffuse pattern of expression, no attempt was made to repeat in situ hybridization with a GluR3 probe. However, the possibility remains that a small subset of cells in optic nerve express GluR3 at appreciable levels, but a more likely possibility is that, as suggested by the absence of a GluR 3 signal in Northern blot analysis, many cells express very low levels that would be difficult to resolve with in situ hybridization histochemistry.

\section{The flip versions of GluR1 and GluR3 genes are expressed in optic nerve}

GluR1, GluR2, GluR3, and GluR4 exist in two versions that result from the alternate splicing of exons, termed flip and flop, 


\section{P21 Optic Nerve}

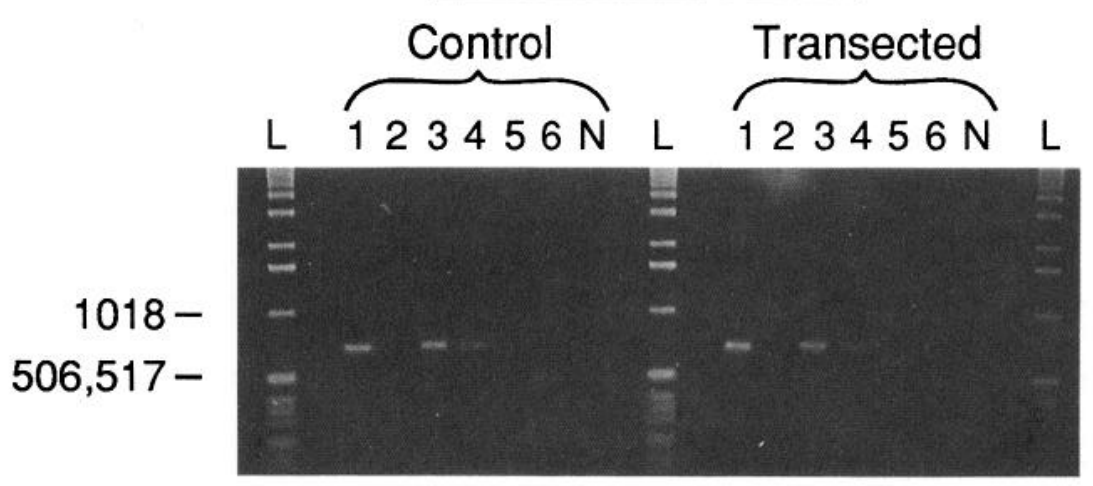

\section{Adult Optic Nerve}

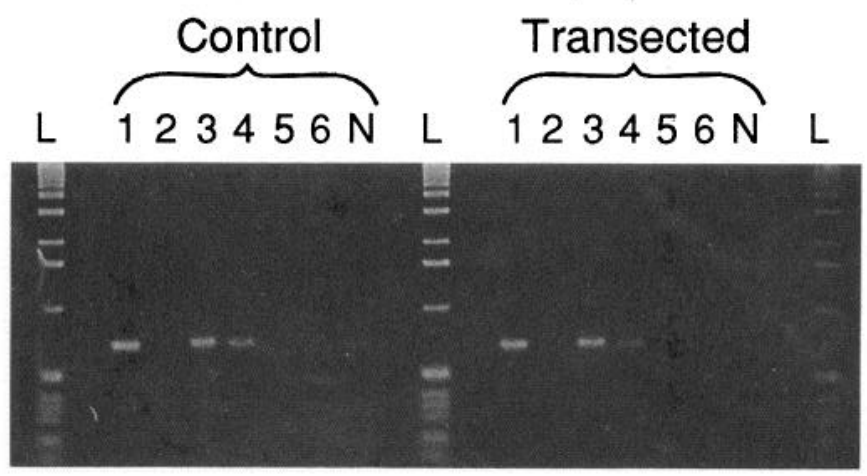

Figure 6. PCR analysis of GluR genes in transected optic nerves. Axons were cut at the eye end and allowed to degenerate in vivo for 5-6 d. Upper panel, PCR analysis of P21 control (untransected) and contralateral transected optic nerve. Lower panel, PCR analysis of adult control (untransected) and transected optic nerve. The same amount of mRNA was added to all reactions within each group but not necessarily between groups (i.e., amount of mRNA in control P21 optic nerve reactions not necessarily equal to P21 transected optic nerve reactions). Molecular weights are standardized with the DNA ladder $(L)$ from GIBCO/BRL. which produce different pharmacological and kinetic properties of the expressed channel (Sommer et al., 1990). To determine the alternative splice variant present in optic nerve, restriction site mapping of the GluR1 PCR product was performed. There is an $A l u \mathrm{I}$ restriction site in the GluR 1 -flip sequence that is absent in the GluR 1-flop sequence; conversely, there is an ScrFI restriction site in the GluR1-flop sequence that is absent in the GluR 1-flip sequence (Fig. 5A). Consequently, parallel digestion of the GluR1 PCR product with these two enzymes results in DNA fragments that are characteristic of the flip or flop exon (Fig. 5B). Enzymatic digestion with AluI and ScrFI of the GluR 1 PCR product from optic nerve (P2, P15, and adult) produces fragment sizes that are predicted for the expression of the flip version (Fig. $5 C$ ). As expected, digestion of GluR1 PCR product from whole brain produces fragment sizes predicted if both flip and flop versions are expressed (Fig. $5 C$ ). The small amount of undigested DNA in the optic nerve $A l u \mathrm{I}$ reactions could result either from incomplete digestion, or from a small proportion of GluR1 that is the flop version that is unresolvable by $S c r F I$ digestion.

Although DNA was amplified by primers presumably specific for the GluR3 gene, no GluR3 message was detected in Northern blot analysis of optic nerve. This raises the possibility that either GluR 3 was too low to be detected by Northern blot as suggested earlier or the amplified product was of an unrelated gene. Therefore, a limited restriction site mapping was performed to confirm the authenticity of the PCR product and, in addition, to deter- mine which of the alternative splice versions of GluR3 (flip or flop) is expressed. According to the published sequence (Sommer et al., 1990), the GluR3 PCR product should contain an AccI restriction site (outside flip/flop region) and an $\mathrm{HpaI}$ site if it is the flip version. Digestion of the optic nerve GluR3 PCR products (all ages) with these restriction enzymes generated fragments of the predicted sizes and indicated that the GluR3 flip version is present in optic nerve tissue (data not shown).

\section{Expression of GluR genes following optic nerve transection}

Transection of the optic nerve at the eye end was performed to examine if glial GluR expression was affected by the loss of axons and also to test the unlikely possibility that the GluR1 (and GluR3) expression detected in optic nerve was due to axonal message. Axons were allowed to degenerate for 5-6 d in vivo before the transected nerves were isolated for GluR message analysis (see Materials and Methods). Figure 6 shows the results of PCR analysis comparing GluR expression in transected and untransected nerves of P21 and adult rats. No changes in GluR expression could be detected by PCR, as compared with the contralateral untransected nerve. However, since quantitative PCR was not performed, small changes, either up or down, in those GluRs already readily amplified would not be revealed.

\section{Expression of an $m G l u R$ gene in optic nerve}

Previous experiments have demonstrated the functional expression of mGluRs in cultured astrocytes that are coupled to 


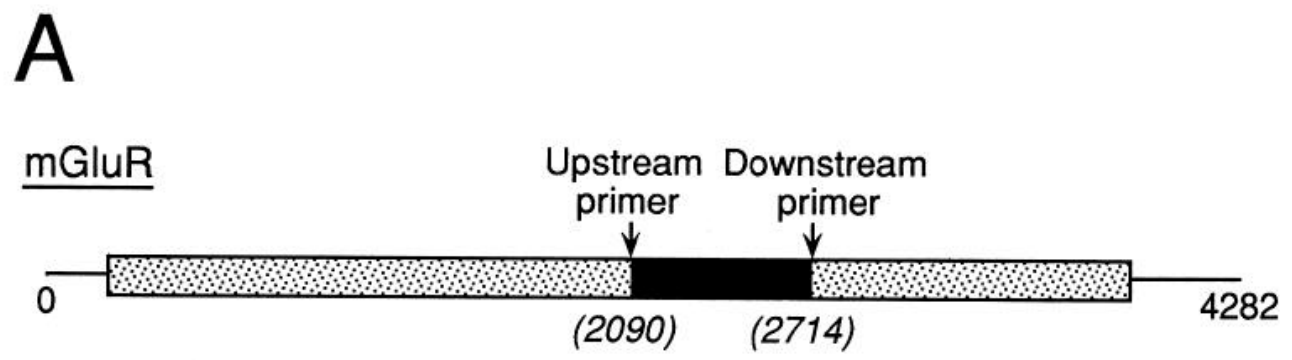

Figure 7. PCR analysis of a gene for an mGluR in optic nerve. $A$, Schematic illustrations of the mGluR gene tested for in PCR; coding regions are indicated by stippled boxes, region targeted for PCR amplification by solid box. The first base of the upstream primer site and the last base of the downstream primer site are indicated with arrows and the numbers given below in parentheses. $B$, Visualization of mGluR PCR product by gel electrophoresis and ethidium bromide staining. A portion $(15 \mu \mathrm{l})$ of the PCR reaction was run on $1.8 \%$ agarose gel. The amount of mRNA added to each reaction was not quantified. The sizes of the PCR products are standardized according to the size ladder (GIBCO/BRL) flanking the PCR reactions as indicated by $L$.

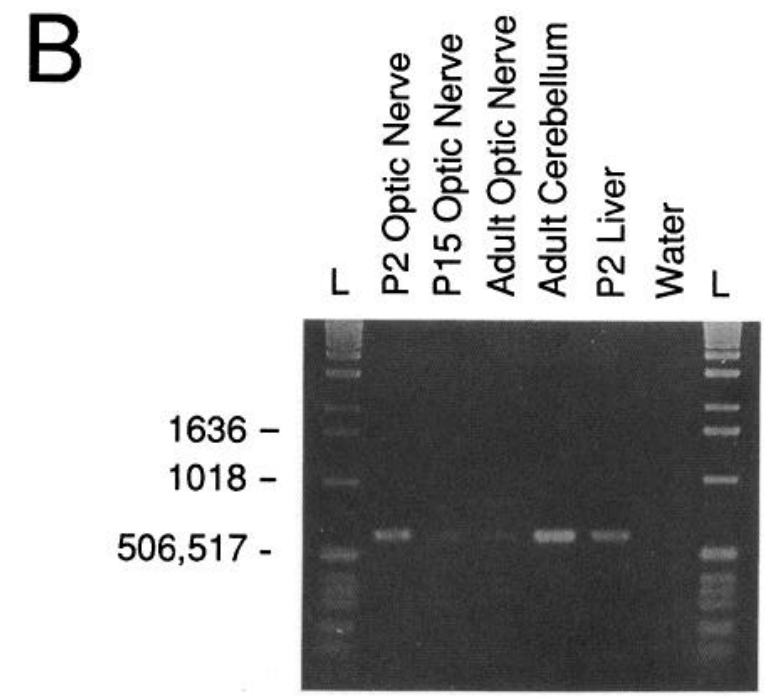

the inositol phospholipid/ $\mathrm{Ca}^{2+}$ pathway (Pearce and Murphy, 1988). Therefore, in addition to identifying expression of ionotropic GluR genes, PCR analysis was used to determine if the cloned mGluR (Masu et al., 1991) is expressed in optic nerve. Following reverse transcription of mRNA with random hexamer primers, PCR was performed using primers chosen according to the published mGluR sequence (Fig. 7A) (Masu et al., 1991), which codes for a receptor that is G-protein-coupled to the inositol phospholipid/ $\mathrm{Ca}^{2+}$ pathway. Figure $7 B$ shows that DNA of the predicted size was amplified from optic nerve at all ages tested, P2, P15, and adult, as well as from adult cerebellum, and surprisingly, from P2 liver. Differences in the amount of DNA amplification across tissue samples do not necessarily reflect differences in expression levels because the amount of starting mRNA was not quantified.

It is possible, but unlikely, that the amplification of mGluR from optic nerve and liver could arise from genomic DNA, because unlike GluR1 and GluR3, there have been no reports of introns within the region between the mGluR primers used in these experiments (Houamed et al., 1991; Tanabe et al., 1992). However, since the same mRNA samples were used in the mGluR PCR reactions as those in the GluR reactions, which failed to amplify genomic DNA in either optic nerve or liver, it seems unlikely there was any contamination of genomic DNA in the mRNA samples.

Although the amplified DNA was of the predicted size, restriction site mapping was performed to confirm further that the amplified DNA was authentic mGluR. According to the published mGluR sequence (Masu et al., 1991), there are three $A l u \mathrm{I}$ sites and one $A c c \mathrm{I}$ site within the mGluR region that was targeted in PCR (Fig. $8 A$ ). Figure $8 C$ shows that enzymatic digestion with $A l u \mathrm{I}$ and $A c c \mathrm{I}$ of the mGluR PCR product from optic nerve (P2, P15, and adult), cerebellum, and liver produces fragment sizes that are predicted for the expression of the targeted mGluR (Fig. $8 B$ ).

\section{Discussion}

To our knowledge, this article is the first to identify the glutamate receptor genes expressed in a mammalian white matter that is completely devoid of synapses and neuronal cell bodies. Since the predominant cell type in optic nerve is glia, we suggest that the detected message for glutamate receptors for both the ionotropic and metabotropic classes, originates in glia. Electrophysiological recordings have previously revealed glutamategated ion channels in freshly isolated glial cells from rat optic nerves (Barres et al., 1990a) and in glial cells from mouse corpus callosum slices (Berger et al., 1992).

\section{Expression of ionotropic GluR genes}

Among the various GluR genes tested (GluR1-GluR6, NMDAR), only GluR 1 is expressed at significant levels in optic nerve. Even though PCR analysis revealed a consistent signal for GluR3 (Fig. 1), the fact that we failed to detect GluR3 message in Northern blot analysis suggests that GluR3 gene was expressed at a very low level only picked up by the sensitivity of PCR. The expression of only GluR 1 in white matter is different 


\section{A Map of restriction sites in mGluR DNA amplified by PCR}

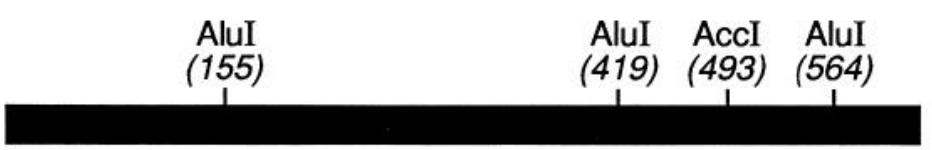

(length $=624$ base pairs)

\section{Predicted sizes of restriction fragments (in base pairs)}

$\begin{array}{rrr}\frac{\text { AluI }}{60} & \frac{\text { AccI }}{493} \\ 145 & & 131 \\ 150 & & \\ 264 & & \end{array}$

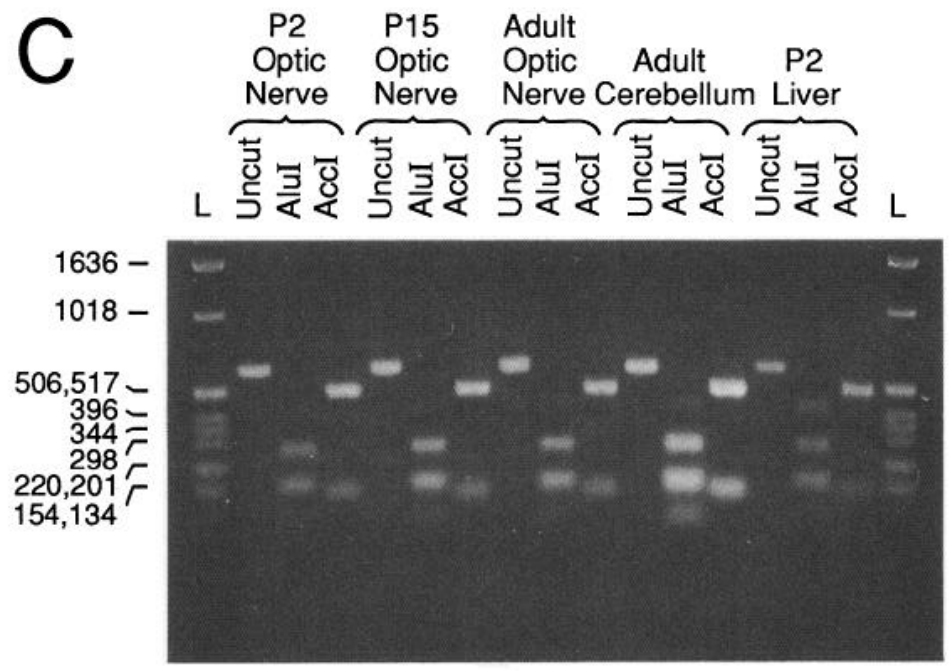

Figure 8. Restriction map of mGluR PCR product. $A$, Map of $A l u \mathrm{I}$ and $A c c \mathrm{I}$ restriction sites in the region of the mGluR gene amplified by PCR. $B$, Predicted sizes of the fragments generated by enzymatic digestion with $A l u \mathrm{I}$ and $A c c \mathrm{I}$ of mGluR PCR products. $C$, Uncut PCR product and $A l u \mathrm{I}$ and $A c c \mathrm{I}$ enzymatic digestions and of $\mathrm{P} 2, \mathrm{P} 15$, adult optic nerve, adult cerebellum, and P2 liver mGluR PCR products were run on a $1.8 \%$ agarose gel and stained with ethidium bromide. Molecular weights are standardized with the DNA ladder $(L)$ from GIBCO/BRL. from that observed for gray matter glia, namely, putative Bergmann glia in cerebellum, which express both GluR1 (GluR-A) and GluR4 (GluR-D) (Burnashev et al., 1992b).

We believe that of the various glial cell types present in optic nerve (oligodendrocytes, astrocytes, and O-2A progenitors; Raff, 1989), O-2A cells are the most likely source of the detected GluR 1 message. First, in patch-clamp studies of freshly isolated glial cells from optic nerves, only O-2A cells showed glutamategated ion channels (Barres et al., 1990a). Second, glutamategated ion channels were not found in freshly isolated type 1 astrocytes from optic nerves (Barres et al., 1990b), although glutamate receptor channels can develop after long-term culture (Wyllie et al., 1991). Third, even though type 2 astrocytes express glutamate receptors in culture (Usowicz et al., 1989; Wyllie et al., 1991), no type 2 astrocytes could be found in freshly dissociated P7 optic nerve (Barres et al., 1990b). Finally, recent experiments using quisqualate-induced cobalt uptake to visualize O-2A progenitor cells in optic nerve in situ (Fulton et al., 1992) further support the idea that it is O-2A progenitor cells that express glutamate-gated channels.
An intriguing observation is that only GluR 1 seems to be expressed at appreciable levels in optic nerve. When GluR1 cDNA is expressed alone in Xenopus oocytes (Boulter et al., 1990) or in human embryonic kidney cells (Verdoorn et al., $1991)$, the current-voltage $(I / V)$ relationship is strongly inwardly rectifying, whereas glutamate-gated currents in optic nerve O-2A progenitor cells are not inwardly rectifying (Barres et al., 1990a; Wyllie et al., 1991). Several possibilities exist that could explain the discrepancy in the $I / V$ relationship seen in Xenopus oocytes and in O-2A progenitor cells. (1) Glial cells process GluR 1 in a manner different from expression systems. (2) Optic nerve GluR1 could exist in an edited form of the mRNA, as has been seen in GluR-B (GluR2), where a glutamate is replaced by an arginine changing a nonlinear $I / V$ relationship into a linear one (Burnashev et al., 1992a). (3) GluR3, and possibly GluR4 (as it occasionally was detected by PCR; Figs. 1, 6), could pair with GluR 1 to yield a functional channel that is nonrectifying. However, in Xenopus oocytes coexpression of GluR1-flop and GluR3-flop also produces an inwardly rectifying $I / V$ relationship (Boulter et al., 1990). (4) in white matter glia, an additional 
subunit(s) is expressed that either was not tested for in these experiments, that is, GluR7 (Bettler et al., 1992), or has yet to be identified.

It is interesting to note that both GluR1 and GluR2 are expressed in long-term cultures ( $\sim 2$ months) of mixed cortical glia, consisting mainly of type 1 astrocytes, type 2 astrocytes, and O-2A progenitor cells (Jensen and Chiu, 1991b). It is not clear whether this difference results from the different brain regions tested, that is, gray (cortical) matter versus white (optic nerve) matter, or results from changes in response to culture conditions and the long-term deprivation of neuronal contact. The interesting possibility remains that the plasticity of GluR2 expression may be used to modulate calcium permeability of glial glutamate receptor channels under different conditions.

The lack of GluR2 expression (Fig. 1 and Northern blot not shown) in optic nerve would suggest that the GluR channels in optic nerve may be permeable to calcium $\left(\mathrm{Ca}^{2+}\right)$ because coexpression of the GluR2 subunit with GluR1 or GluR3 renders the expressed channel impermeable to $\mathrm{Ca}^{2+}$ (Hollmann et al., 1991). In addition, quisqualate-induced cobalt uptake, considered an indicator of calcium permeability (Pruss et al., 1991), has been demonstrated in O-2A cells in optic nerve in situ (Fulton et al., 1992). However, the linear $I / V$ relationship of glutamate currents in O-2A progenitors (Barres et al., 1990a; Wyllie et al., 1991) is different than that seen of other $\mathrm{Ca}^{2+}$ permeable glutamate-gated channels, both in expression systems (Hollmann et al., 1991; Verdoorn et al., 1991; Burnashev et al., 1992a) and in mammalian neurons (Iino et al., 1990), both of which are rectifying. Interestingly, glial cells in gray matter, namely, cerebellar Bergmann glia (Muller et al., 1991) and cultured ccrebellar fusiform astrocytes (Burnashev et al., 1992b), express glutamate-gated channels that are permeable to $\mathrm{Ca}^{2+}$.

The diffuse pattern of GluR1 expression, as viewed by in situ hybridization histochemistry in P15 and adult optic nerve (Fig. 4 ), could be due to the combination of two factors: (1) the uniform distribution of $\mathrm{O}-2 \mathrm{~A}$ progenitor cells that is seen by P15 and in the adult optic nerve (Fulton et al., 1992), and (2) the GluR 1 message may be targeted to processes that extend widely throughout the nerve (Fulton et al., 1992). The increase in GluR 1 message may be concommitant with the increase and elaboration of the processes of $\mathrm{O}-2 \mathrm{~A}$ progenitor cells during development (Fulton et al., 1992). Furthermore, it seems unlikely that the GluR 1 message in optic nerve, as detected by PCR, Northern blot analysis, and in situ hybridization histochemistry, results from axonal expression, since a similar pattern of GluR expression is seen following nerve transection (Fig. 5). In addition, there does not appear to be a reactive change in the subtypes of GluRs that are expressed in response to the loss of axons.

\section{Expression of a metabotropic glutarnate receptor gene}

The expression of mGluR (Masu et al., 1991) in developing and adult optic nerve was detected by PCR (Fig. 8). A limited mapping of restriction sites in the $\mathrm{MGluR}$ PCR product was as would be predicted for the expression of $\mathrm{mGluR}$. However, additional experiments not performed in this study, such as Northern blot analysis and in situ hybridization histochemistry, could provide important information as to the level and distribution of $m$ GluR expression in optic nerve. The results shown in Figure 7 suggest that there might be a developmental change in mGluR expression, being higher in earlier postnatal periods (even though a quantitative PCR analysis is needed to address this issue). In preliminary experiments in our laboratory using confocal imaging of intracellular $\mathrm{Ca}^{2+}$ in intact $\mathrm{P} 7$ rat optic nerves, application of glutamate or trans-1-amino-cyclopentyl-1,3-dicarboxylic acid (t-ACPD; a selective mGluR agonist), or repetitive electrical nerve stimulation, evokes $\mathrm{Ca}^{2+}$ oscillations, a hallmark of mGluR activation, in presumptive glial cells (Kriegler and Chiu, 1992).

In conclusion, the specificity of glutamate receptor expression in optic nerve is presumably related to the function of optic nerve glia. What this function is remains to be determined. It is intriguing that our in situ hybridization histochemistry results suggest that the message for this protein may be uniformly distributed in glia, both near the cell soma and in processes. Unlike gray matter where glutamate is relcascd discrctcly at synapses, in white matter glutamate may be released diffusely along the entire axons via reverse glutamate uptake. It remains possible that there is a functional link between this diffuse pattern of glutamate release and the diffuse pattern of message distribution in glia. Perhaps this allows, in a single glial cell that serves multiple axons, local processing of signals between individual glial processes and their axonal partners in an autonomous fashion. The in vivo expression of glutamate receptor genes in both developing and adult optic nerve suggests that neurotransmittermediated signaling is an integral part of normal signaling in nonsynaptic regions of the brain. Furthermore, the $\mathrm{Ca}^{2+}$ permeability of glutamate receptor channels in many types of glia indicates that this second messenger may be of primary importance in glial signaling rather than the rapid, large changes in membrane potential observed in neurons, few of which express $\mathrm{Ca}^{2+}$-permeable glutamate channcls (Iino ct al., 1990; Gilbertson et al., 1991).

\section{References}

Barres BA (1991) New roles for glia. J Neurosci 11:3685-3694.

Barres BA, Koroshetz WJ, Swartz KJ, Chun LLY, Corey DP (1990a) Ion channel expression by white matter glia: the O-2A glial progenitor cell. Neuron 4:507-524.

Barres BA, Koroshetz WJ, Chun LLY, Corey DP (1990b) Ion channel expression by white matter glia: the type-1 astrocyte. Neuron 5:527544.

Berger T, Walz W, Schnitzer J, Kettenmann H (1992) GABA- and glutamate-activated currents in glial cells of the mouse corpus callosum slice. J Neurosci Res 31:21-27.

Bettler BJ, Boulter J, Hermans-Borgmeyer I, O'Shea-Greenfield A, Deneris EC, Moll C, Borgmeyer U, Hollmann M, Heinemann S (1990) Cloning of a novel glutamate receptor subunit, GluR5: expression in the nervous system during development. Neuron 5:583-595.

Bettler BJ, Egebjerg J, Sharma G, Pecht G, Hermans-Borgmeyer I, Moll C, Stevens CF, Heinemann S (1992) Cloning of a putative glutamate receptor: a low affinity kainate-binding subunit. Neuron 8:257-265.

Black JA, Waxman SG (1988) The perinodal astrocyte. Glia 1:169183.

Boulter J, Hollmann M, O'Shea-Greenfield A, Hartley M, Deneris E, Maron C, Heinemann S (1990) Molecular cloning and functional expression of glutamate receptor subunit genes. Science 249:10331037.

Burnashev N, Monyer H, Seeberg PH, Sakmann B (1992a) Divalent ion permeability of AMPA receptor channels is dominated by the edited form of a single subunit. Neuron 8:189-198.

Burnashev N, Khodorova A, Jonas P, Helm PJ, Wisden W, Monyer H, Seeberg PH, Sakmann B (1992b) Calcium-permeable AMPAkainate receptors in fusiform cerebellar glial cells. Science 256:15661569.

Chomczynski P, Sacchi N (1987) Single-step method of RNA isolation by acid guanidinium thyiocyanate-phenol-chloroform extraction. Anal Biochem 162:156-159.

Cornell-Bell AH, Finkbeiner SM, Cooper MS, Smith SJ (1990) Glu- 
tamate induces calcium waves in cultured astrocytes: long-range glial signaling. Science 247:470-473.

Dani JW, Chernjavsky A, Smith SJ (1992) Neuronal activity triggers $\mathrm{Ca}^{3+}$ wavcs in hippocampal astrocyte networks. Neuron 8:1-20.

Egebjerg J, Bettler B, Hermans-Borgmeyer I, Heinemann S (1991) Cloning of a cDNA for a glutamate receptor subunit activated by kainate but not AMPA. Nature 351:745-748.

Enkvist MOK, Holopainen I, Akerman KEO (1989) Glutamate receptor-linked changes in membrane potential and intracellular $\mathrm{Ca}^{2+}$ in primary rat astrocytes. Glia 2:397-402.

Fulton BP, Burne JF, Raff MC (1992) Visualization of O-2A progenitor cells in developing and adult rat optic nerve by quisqualatestimulated cobalt uptake. J Neurosci 12:4816-4833.

Gallo V, Upson LM, Hayes WP, Vyklicky L, Winters CA, Buonanno A (1992) Molecular cloning and developmental analysis of a new glutamate receptor subunit isoform in cerebellum. J Neurosci 12: 1010-1023.

Gilbertson TA, Scobey R, Wilson M (1991) Pcrmcation of calcium ions through non-NMDA glutamate channels in retinal bipolar cells. Science 251:1613-1615.

Glaum SR, Holzwarth JA, Miller RJ (1990) Glutamate receptors activate $\mathrm{Ca}^{2+}$ mobilization and $\mathrm{Ca}^{2+}$ influx into astrocytes. Proc Natl Acad Sci USA 47:129-136.

Hollmann M, O'Shea-Greenfield A, Rogers SW, Heinemann S (1989) Cloning by functional expression of a member of the glutamate receptor family. Nature 342:643-648.

Hollmann M, Hartley M, Heinemann S (1991) $\mathrm{Ca}^{2+}$ permeability of KA-AMPA-gated glutamate receptor channels depends on subunit composition. Science 252:851-853.

Houamed KM, Kuijper JL, Gilbert TL, Haldeman BA, O'Hara PJ, Mulvihill ER, Almers W, Hagen FS (1991) Cloning, expression and gene structure of a $\mathrm{G}$ protein-coupled glutamate reccptor from rat brain. Science 252:1318-1321.

Iino M, Ozawa S, Tsuzuki K (1990) Permeation of calcium through excitatory amino acid receptor channels in cultured rat hippocampal neurones. J Physiol (Lond) 424:151-165.

Jensen A, Chiu SY (1990) Fluorescence measurement of changes in intracellular calcium induced by excitatory amino acids in cultured cortical astrocytes. J Neurosci 10:1165-1175.

Jensen A, Chiu SY (1991a) Differential intracellular calcium responses to glutamate in type-1 and type-2 culture brain astrocytes. J Neurosci 11:1674-1684.

Jensen A, Chiu SY (1991b) Ionotropic glutamate receptor mRNA expression in cultured rat brain astrocytes and rat optic nerve. Soc Neurosci Abstr 17:27.5.

Keinanen K, Wisden W, Sommer B, Wcrner P, Herb A, Verdoorn TA, Sakmann B, Seeburg PH (1990) A family of AMPA-selective glutamate receptors. Science 249:556-560.

Kriegler S, Chiu SY (1992) Glial calcium signaling in intact mammalian white matter. Soc Neurosci Abstr 18:185.7.

Kumar KN, Tillakaratne N, Johnson PS, Allen AE, Michaelis EK (1991) Cloning of a cDNA for the glutamate-binding subunit of a NMDA receptor complex. Nature 354:70-74.
Masu M, Tanabe Y, Tsuchida K, Shigemoto R, Nakanishi D (1991) Sequence and expression of a metabotropic glutamate receptor. Nature 349:760-765.

Moriyoshi K, Masu M, Ishii T, Shigemoto R, Mizuno N, Nakanishi S (1991) Molecular cloning and characterization of the rat NMDA receptor. Nature 354:31-37.

Muller T, Moller T, Berger T, Schnitzer J, Kettenmann H (1991) Calcium entry through kainate receptors and resulting potassium-channel blockade in Bermann glial cells. Science 256:1563-1566.

Nakanishi N, Shneider NA, Axel R (1990) A family of glutamate receptor genes: evidence for the formation of heteromultimeric receptors with distinct channel properties. Neuron 5:569-581.

Pearce B, Murphy S (1988) Neurotransmitter receptors coupled to inositol phospholipid turnover and $\mathrm{Ca}^{2+}$ flux: consequences for astrocyte function. In: Glial cell receptors (Kimelberg HK, ed), pp $197-$ 221. New York: Raven.

Pearce B, Albrecht J, Morrow C, Murphy S (1986) Astrocyte glutamate receptor activation promotes inositol phospholipid turnover and calcium flux. Neurosci Lett 72:335-340.

Pellegrini-Giampietro DE, Bennett MVL, Zukin RS (1991) Differential expression of three glutamate receptor genes in developing rat brain: an in situ hybridization study. Proc Natl Acad Sci USA 88: 4157-4161.

Pruss RM, Akeson RL, Racke MM, Wilburn JL (1991) Agonist-activated cobalt uptake identifies divalent cation-permeable kainate receptors on neurons and glial cells. Neuron 7:509-518.

Raff MC (1989) Glial cell diversification in the rat optic nerve. Science 243:1450-1455.

Rakic P, Sidman RL (1971) Neuron-glia relationship during granule cell migration in developing cerebellar cortex. A Golgi and electron microscopic study in macacus rhesus. J Comp Neurol 141:283-312.

Sommer B, Kcinanen K, Verdoorn TA, Wisden W, Burnashev N, Herb A, Kohler M, Takagi T, Sakmann B, Seeburg PH (1990) Flip and flop: a cell-specific functional switch in glutamate-operated channels of the CNS. Science 249:1580-1585.

Sontheimer H, Kettenmann H, Backus KH, Schachner M (1988) Glutamate opens $\mathrm{Na}^{+} / \mathrm{K}^{+}$channels in cultured astrocytes. Glia $1: 328-$ 336.

Tanabe Y, Masu M, Ishii T, Shigemoto R, Nakanishi D (1992) A family of metabotropic glutamate receptors. Neuron 8:169-179.

Usowicz MM, Gallo V, Cull-Candy SG (1989) Multiple conductance channels in type- 2 cerebellar astrocytes activated by excitatory amino acids. Nature 339:380-383.

Verdoorn TA, Burnashev N, Monyer H, Seeberg PH, Sakmann B (1991) Structural determinants of ion flow through recombinant glutamate receptor channels. Science 252:1715-1718.

Wilkin GP, Marriot DR, Cholewinski AJ (1990) Astrocyte heterogeneity. Trends Neurosci 13:43-46.

Wyllie DJA, Mathie A, Symonds CJ, Cull-Candy SG (1991) Activation of glutamate receptors and glutamate uptake in identified macroglial cells in rat cerebellar cultures. J Physiol (Lond) 432:235-258. 